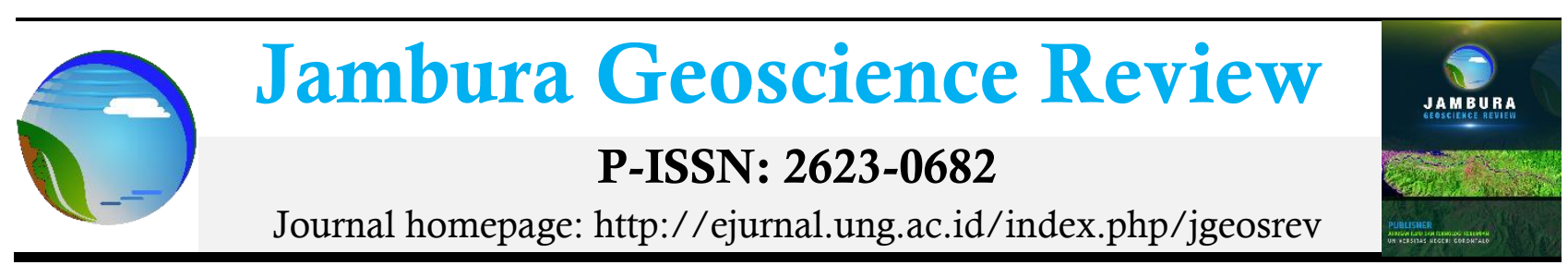

\title{
GEOLOGI DAERAH DIMITO DAN SEKITARNYA KABUPATEN BOALEMO PROVINSI GORONTALO
}

\author{
Alifia Widya Warapsari Badaru ${ }^{\mathrm{a}}$, Fitryane Lihawa ${ }^{\mathrm{b}}$, Intan Noviantari Manyoe ${ }^{\mathrm{a}}$ \\ a Teknik Geologi, Universitas Negeri Gorontalo, Gorontalo 96128, Indonesia \\ ${ }^{b}$ Pendidikan Geografi, Universitas Negeri Gorontalo, Gorontalo 96128, Indonesia
}

\section{INFO ARTIKEL}

\section{Status artikel:}

Diterima: 15 Desember 2018

Disetujui: 5 Januari 2019

Tersedia online: 30 Januari 2019

\section{Keywords:}

Boalemo, Dimito, Geology, Gorontalo, Stratigraphy, Structure

Penulis korespondensi:

Alifia Widya Warapsari Badaru

Teknik Geologi, Universitas Negeri

Gorontalo, Gorontalo, Indonesia

Email: jaejoker@gmail.com

\begin{abstract}
Administratively, the research area covers two districts, Wonosari Sub-district and Dulupi Sub-district, Boalemo District, Gorontalo Province. Based on the physiography of the Gorontalo region, the research area which is included in the southern mountain zone of Bone-Tilamuta-Modello generally consists of ancient volcano-sedimentary rock formations in Gorontalo, the Eocene-Oligocene. The purpose of this geological research is to discover the geological order that developed in the area of Dimito and surrounding are as covering several aspect such as geomorphology, stratigraphy, geological structure, and geological history. The result shows that the geomorphology of the research area divided into three geomorphic units, namely the units of the Alluvial Plain, Volcanic Hills, and Denudasional Hills. Stratigraphy of the research area divided into five types of units sorted from the early Miocene to the Holocene, i.e., Lava Basal Dimito (Early Eocene), Wackestone Dimito (Early Eocene), Andesit Kalidingin (Middle Miocene), Granodiorite Bualo (Middle Pliocene), and Alluvial Buaolo (Recen). Geological structures that work on the location of the research area relatively trend from northeast-southwest to northwest-southeast. Fault working on the location of the research area from the data processing consists of Normal Left Slip Fault Kalidingin and Lag Left Slip Fault Bualo.
\end{abstract}

Copyright $(2019$ JGeosREV-UNG This open access article is distributed under $a$ Creative Commons Attribution (CC-BY) 4.0 International license

\section{Pendahuluan}

Indonesia merupakan wilayah geologi kompleks yang terletak di tepi tenggara benua Eurasia. Indonesia berbatasan dengan zona tektonik aktif yang ditandai dengan kegempaan tinggi dan vulkanisme sebagai hasil dari subduksi (Hall, 2009). Menurut Hamilton (1979) Sulawesi dibentuk dari tiga unit tektonik utama. Sulawesi telah berkembang di zona konvergensi kompleks Eurasia, Pasifik dan lempeng kerak Australia. Bagian barat Sulawesi yang terdiri atas Lengan Utara dan Lengan Selatan, terbentuk dari rangkaian busur gunungapi-plutonik dari Kapur Akhir.

Gorontalo terletak di Lengan Utara Sulawesi. Aktivitas tektonik di Gorontalo diduga telah berlangsung sejak Eosen sampai Oligosen. Selama Eosen terjadi pemekaran dasar samudera yang berlangsung hingga Miosen Awal dan menghasilkan lava bantal yang cukup luas. Aktivitas ini diikuti pula oleh terjadinya retas-retas yang umumnya bersusunan basa dan banyak menerobos Formasi Tinombo.

Berdasarkan pembagian secara fisiografis (Bemmelen, 1949), daerah Dimito dan sekitarnya merupakan Zona Pegunungan Selatan Bone-Tilamuta-Modello yang umumnya terdiri dari formasiformasi batuan sedimenter gunungapi berumur sangat tua di Gorontalo yaitu Eosen - Oligosen. Hal ini menarik untuk diteliti karena adanya formasi batuan tertua (Formasi Tinombo) dan kegiatan tektonik yang telah berlangsung sejak Eosen di daerah penelitian. Penelitian ini bertujuan untuk mengetahui 


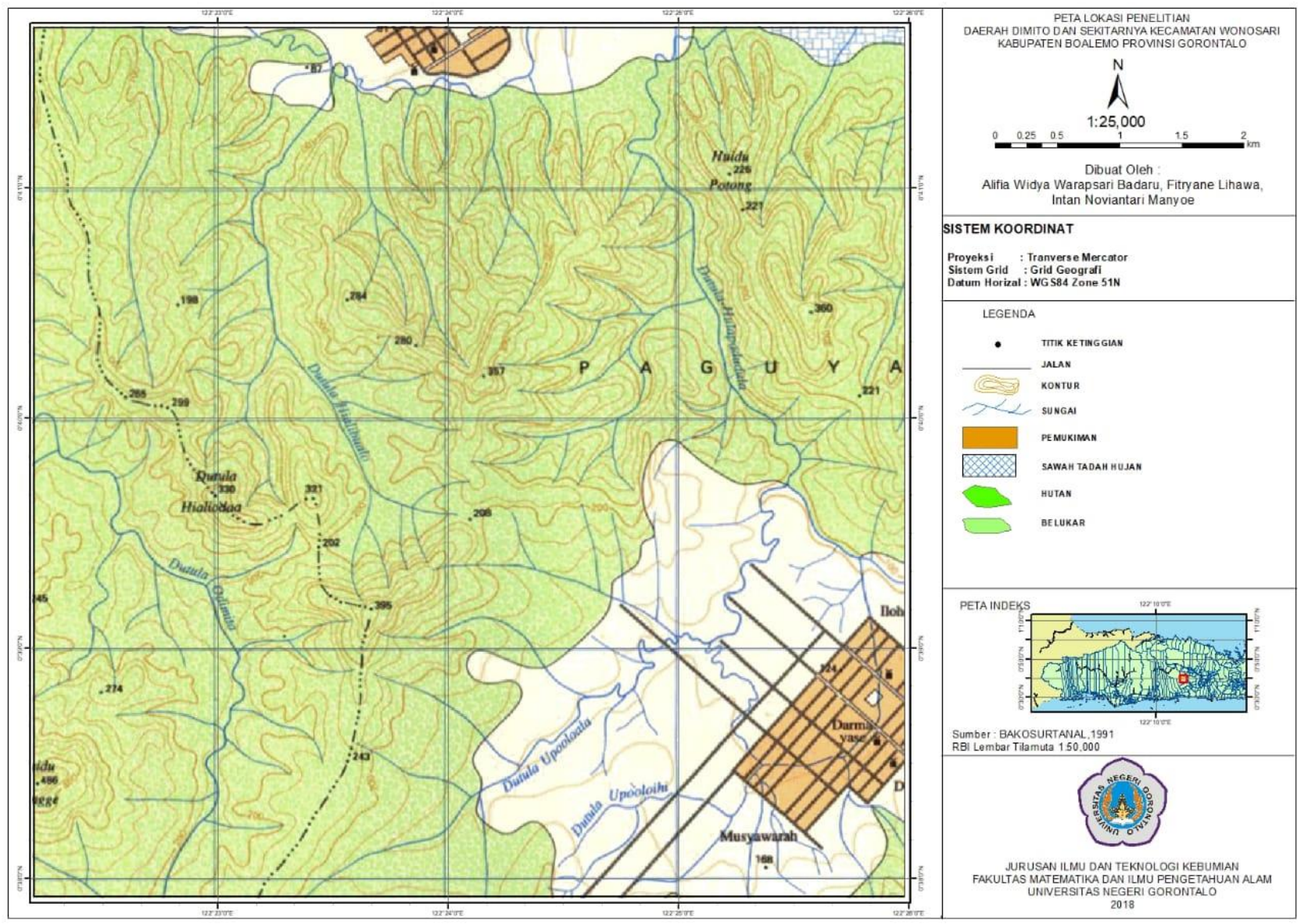

Gambar 1. Peta lokasi penelitian

tatanan geologi yang berkembang di daerah Dimito dan sekitarnya mencakup beberapa aspek yaitu geomorfologi, stratigrafi, sruktur geologi, dan sejarah geologi.

\section{Metodologi}

\subsection{Lokasi Penelitian}

Daerah penelitian terletak pada koordinat $00^{\circ} 37^{\prime} 55.2^{\prime \prime}-00^{\circ} 41^{\prime} 42^{\prime \prime}$ Lintang Utara dan $122^{\circ} 22^{\prime} 12^{\prime \prime}-$ $122^{\circ} 25^{\prime} 58.8^{\prime \prime}$ Bujur Timur dengan luas daerah penelitian $\pm 49 \mathrm{~km}^{2}$. Secara administratif, daerah penelitian mencakup dua kecamatan yaitu Kecamatan Wonosari dan Kecamatan Dulupi, Kabupaten Boalemo, Provinsi Gorontalo.

\subsection{Pengumpulan dan Analisis Data}

Pengumpulan data yang dilakukan dalam penelitian ini berupa pengamatan geomorfologi, deskripsi singkapan, deskripsi litologi, pengukuran struktur geologi, dan dokumentasi. Analisis data yang dilakukan yaitu analisis geomorfologi, petrologi, petrografi, stratigrafi, dan struktur geologi. Klasifikasi yang digunakan untuk analisis geomorfologi adalah klasifikasi Van Zuidam (1985). Klasifikasi untuk analisis petrografi menggunakan klasifikasi Travis (1955), O’Dunn dan Sill (1986), dan Dunham (1962). Klasifikasi untuk analisis petrologi menggunakan Streckeisen (1978) dan Dunham (1962) dan untuk klasifikasi batuan metamorf didasarkan pada kenampakan struktur dan teksturnya. Analisis sesar menggunakan klasifikasi Rickard (1972).

\section{Hasil dan Pembahasan}

\subsection{Geomorfologi}

Morfologi daerah penelitian mencakup bentang alam yang didominasi oleh perbukitan dan dataran dengan interval ketinggian antara 50 - 485 mdpl. Titik terendah berada pada bagian selatan daerah penelitian sedangkan titik tertinggi berada pada bagian barat daerah penelitian. Berdasarkan hasil analisis peta topografi (Gambar 2) dan pengamatan lapangan berupa bentuk sungai, arah aliran sungai, kontrol litologi dan stuktur geologi pada daerah penelitian, maka dibagi pola aliran sungai menurut klasifikasi A.D Howard (1967) menjadi 3 (tiga) pola aliran sungai, yaitu subdendritik, parallel, dan 


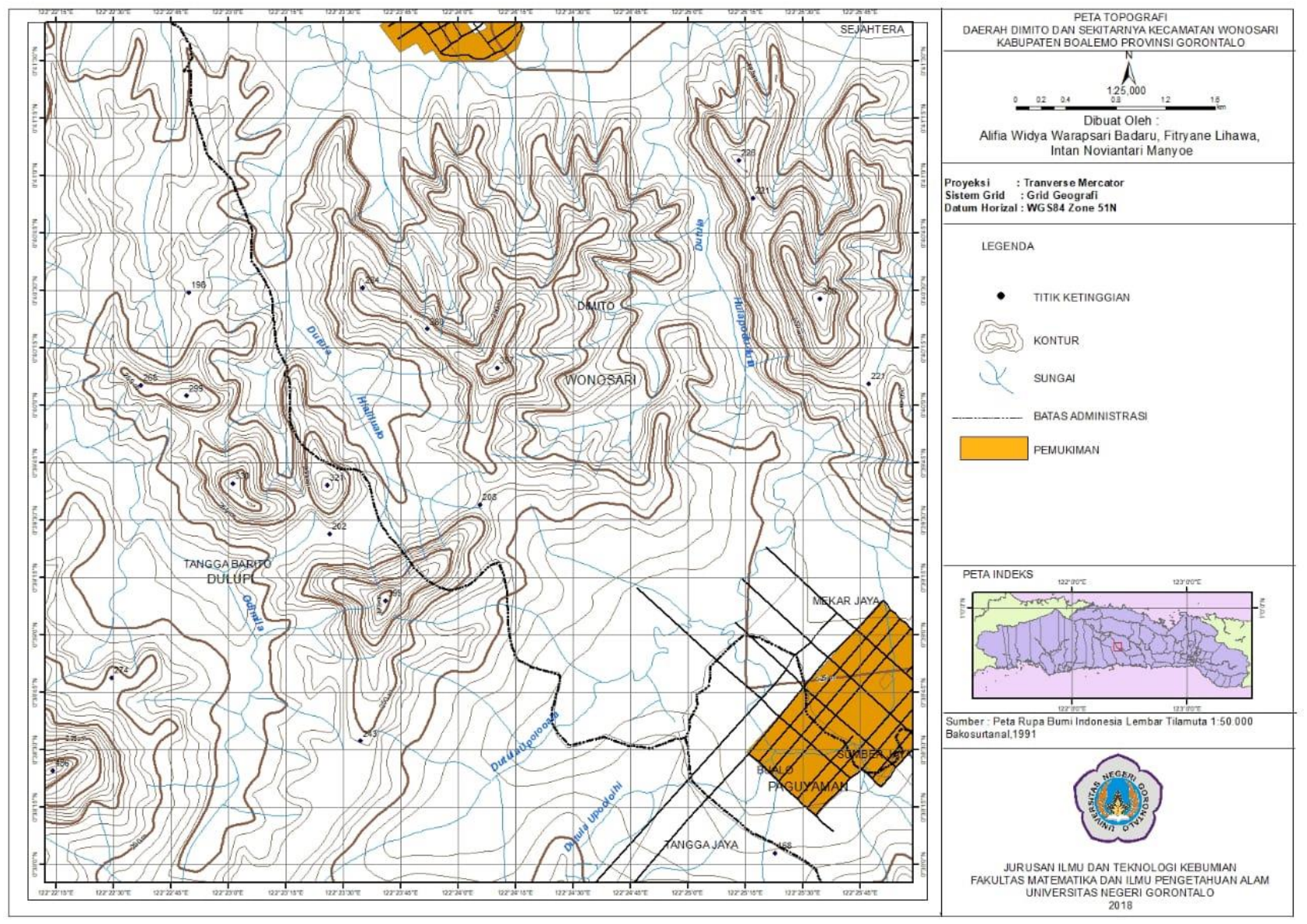

Gambar 2. Peta topografi daerah penelitian

subparallel. Tipe genetik sungai yang terdapat pada daerah penelitian yaitu tipe genetik sungai subsekuen dan konsekuen.

Berdasarkan pengamatan lapangan dan interpretasi peta maka daerah penelitian termasuk dalam stadia geomorfologi muda-dewasa. Stadia geomorfologi muda bisa dilihat pada bentuk profil sungai V, dan adanya arus seimbang antara laju erosi vertikal dan erosi lateral. Pada sungai yang telah mencapai stadium dewasa terdapat dataran banjir yang terbentuk dari pengendapan material klastis yang diendapkan pada daerah di dekat sungai dan lembah, melandai menyerupai huruf U sebagai akibat erosi lateral (Gambar 3a). Relief yang diperlihatkan oleh daerah penelitian adalah bergelombang hingga maksimum dengan bentuk penampang lembah V-U.

Secara umum bentang alam dikontrol oleh faktor litologi, struktur dan proses erosi. Berdasarkan klasifikasi Van Zuidam (1985) yaitu klasifikasi berdasarkan morfografi, morfometri, dan morfogenetik, pembagian bentuklahan pada daerah penelitian menjadi tiga satuan geomorfologi yaitu dataran aluvial, perbukitan aliran lava, dan perbukitan denudasional. Bentuklahan dataran alluvial (Gambar 3b) mempunyai topografi dengan relief datar dan kemiringan lereng landai (2-7\%). Luas dataran alluvial sekitar 20\% dari keseluruhan luas daerah penelitian. Perbedaan elevasi di daerah ini berkisar $75-125$ mdpl. Morfologi berbentuk dataran rendah. Tersusun dari material lepas hasil erosi dan pelapukan dari batuan yang berukuran lempung, pasir, kerikil, hingga bongkah yang terendapkan di channel bar dan point bar. Tata guna lahan pada dataran aluvial adalah pemukiman, pertanian lahan kering dan perkebunan.

Satuan bentuklahan perbukitan Volkanik (Gambar 3d) menempati luasan lebih dari 40\% dari seluruh daerah penelitian. Satuan ini umumnya tersebar dari arah barat ke timur dengan morfologi berupa perbukitan memanjang. Kemiringan lereng curam hingga sangat curam (30 - 70\%) dimana sering terjadi erosi dan gerakan tanah dengan kecepatan yang lambat. Elevasi satuan ini adalah 221-357 mdpl. Secara morfogenesa satuan bentuklahan ini dipengaruhi oleh struktur berupa kekar, sesar dan mempunyai bentuk lembah U-V. Litologi berupa basal dan andesit. Pada satuan geomorfologi ini, tata guna lahan berupa perkebunan kelapa sawit dan kawasan terbuka hijau. 


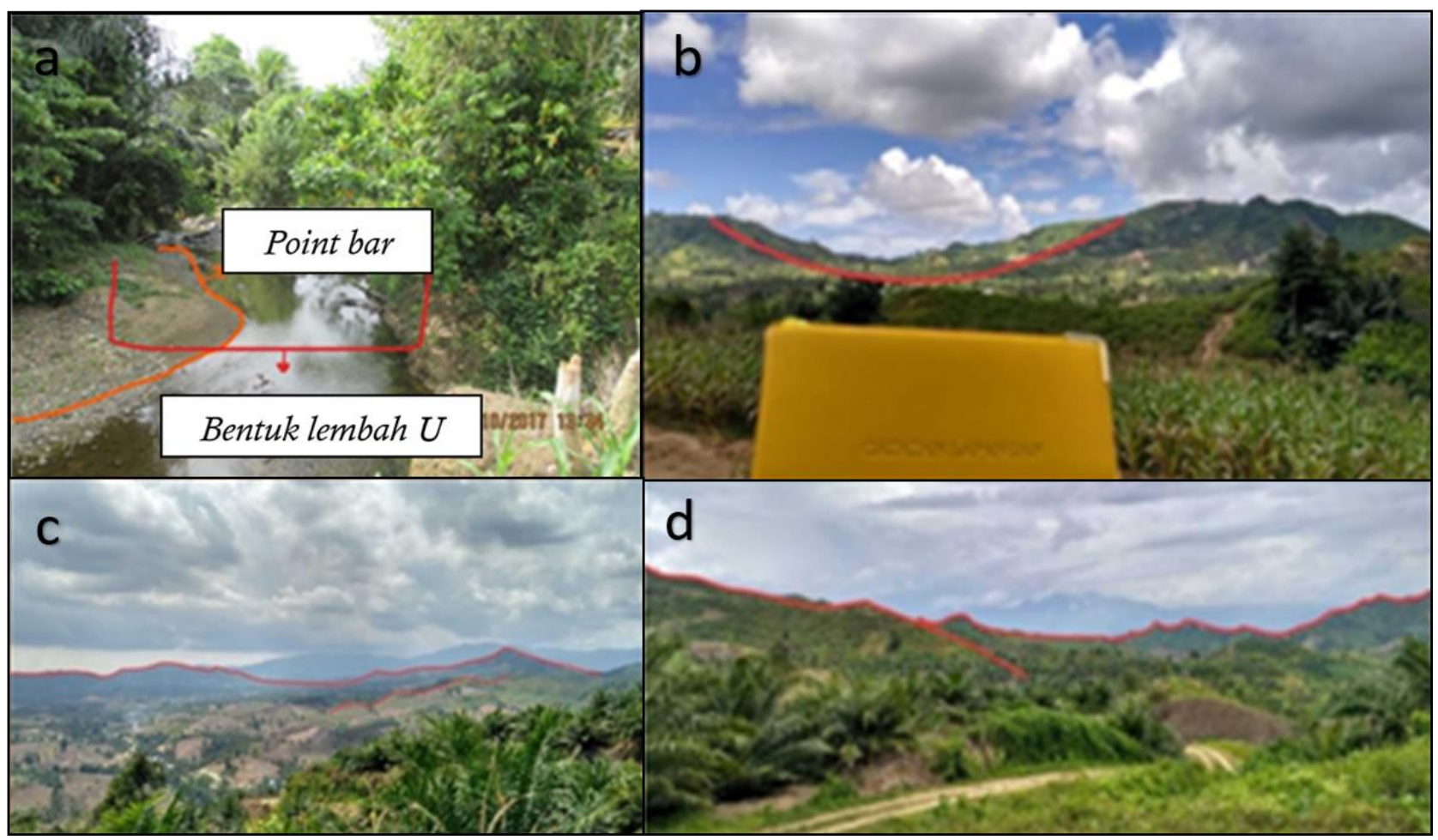

Gambar 3. Kenampakan satuan dan subsatuan geomorfologi; a) point bar, b) dataran alluvial, c) perbukitan denudasional, dan d) perbukitan vulkanik.

Satuan bentuklahan perbukitan denudasional (Gambar 3c) ditandai dengan morfologi perbukitan bergelombang dengan persentase kemiringan secara keseluruhan curam (15\%- 30\%). Bentuk lembah mulai dari U tajam hingga V tumpul. Elevasi mulai dari 100-208 mdpl. Satuan ini menempati sekitar $40 \%$ wilayah dengan persebaran di bagian tengah daerah penelitian. Litologi penyusun bentuklahan berupa batuan basal, granodiorit, dan sedimen yang terendapkan. Morfostuktur aktif berupa sesar dan kekar. Morfodinamik yang memperlihatkan erosi terbagi erosi ke arah lateral (ke samping) dan vertikal (ke dasar sungai), dan adanya pelapukan. Tata guna lahan berupa perkebunan dan pertanian.

\subsection{Stratigrafi}

Stratigrafi daerah penelitian diurutkan dari tua ke muda yaitu satuan Lava Basal Dimito, satuan Wackestone Dimito, satuan Andesit Kalidingin, satuan Granodiorit Bualo, dan satuan Aluvial Bualo.

a. Satuan Lava Basal Dimito

Luas penyebaran satuan Lava Basal Dimito sekitar $44.82 \%$ atau $21.96 \mathrm{~km}^{2}$ dari total luas daerah penelitian. Satuan Lava Basal Dimito terdapat di daerah Tangga Barito, Tangga Jaya, Dusun Kalidingin, dan Dusun Ilomonu. Lava basal pada satuan ini mempunyai ciri litologi berwarna abu-abu tua hingga abu - abu kehijauan. Struktur masif, hipokristalin, porfiri-afanitik, bentuk butir dari euhedral hingga subhedral, dengan hubungan antar butir equigranular. Batuan ini telah mengalami ubahan hidrotermal (Gambar 4b) ditandai dengan hadirnya mineral ubahan kuarsa (berupa gash), mineral pirit, epidot dan zeolite.

Lava andesit pada satuan Lava Basal Dimito dicirikan dengan warna abu-abu hingga abu-abu kehijauan, porfiri afanitik, dengan fenokris mineral seperti kuarsa, biotit, terdapat struktur vein kalsit (Gambar 4d) dan struktur kekar kolom (columnar joint) (Gambar 4c). Ciri lain yang ada dalam satuan batuan ini adalah adanya batuan metamorf. Batuan metamorf yang tersingkap di lapangan terbagi menjadi quartz schist dan metabasal. Ciri litologi berwarna biru kehijauan hingga warna abu-abu terang, besar butir fine to medium coarse, tekstur lepidoblastik, schistose dalam petrografi, kompak, dan pada beberapa daerah telah terkekarkan. Mineral yang dapat dilihat berupa kuarsa, hornblende, biotit, dan mineral seperti epidot dan mika. Protolith metamorf daerah penelitian berasal dari batuan beku basal.

Secara mikroskopis menunjukkan bahwa lava basal (Gambar 4e) berwarna abu - abu gelap hingga colorless, tekstur hipokristalin, subhedral-anhedral, dan inequigranular. Terdapat tekstur khusus intersertal dengan persentase mineral biotit $10 \%$, orthoklas sebanyak $5 \%$, kuarsa $15 \%$ hadir sebagai fenokris, massa gelas $20 \%$, cordierite $5 \%$, feldspar $20 \%$, dan mineral opak $5 \%$. 


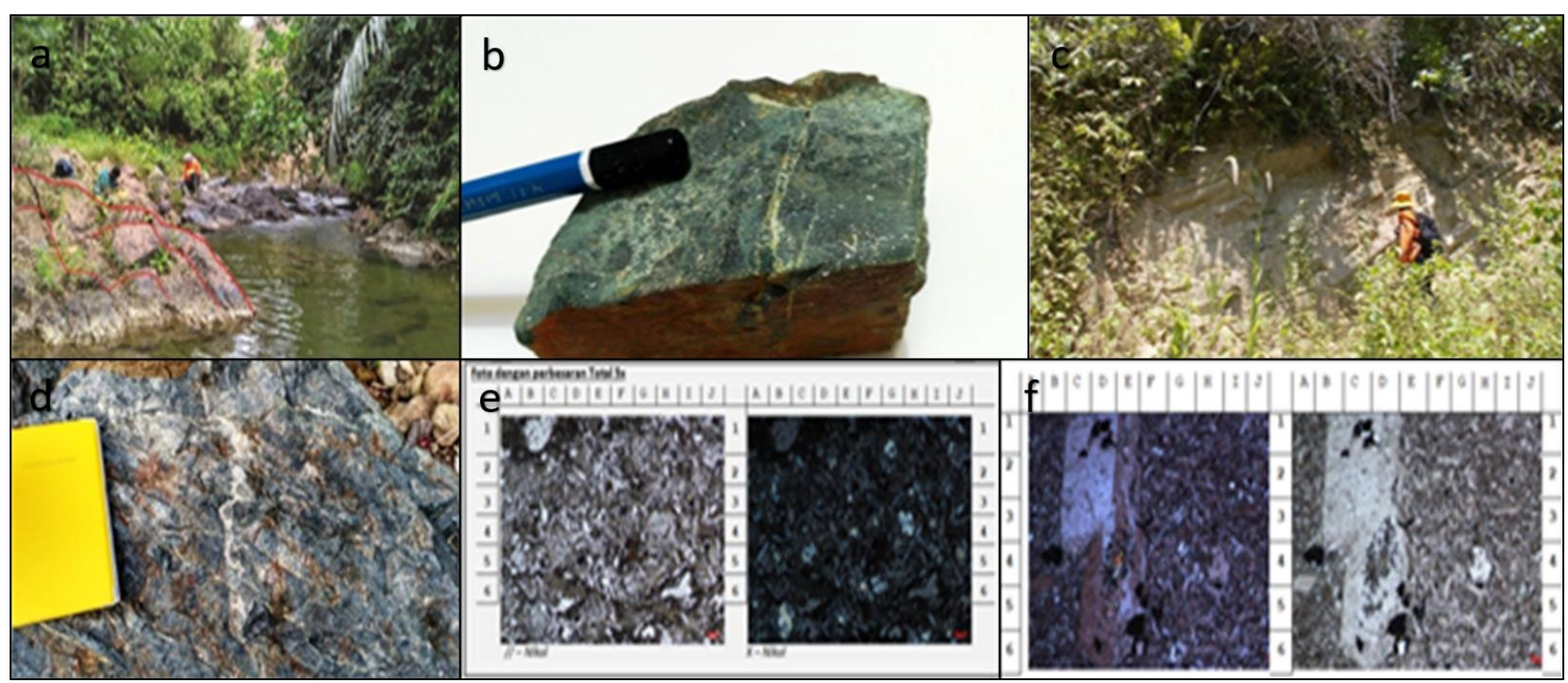

Gambar 4. Kenampakan pada satuan Lava Basal Dimito; a) Struktur pillow lava pada singkapan basal, b) Urat kuarsa dan pirit pada sampel batuan basal sebagai tanda adanya aktivitas hidrotermal, c) Columnar joint pada singkapan andesit, d) metabasal, e) Kenampakan mineral dalam sayatan batuan basal secara mikroskopis dimana Kuarsa hadir sebagai fenokris, f) Kenampakan mineral dalam sayatan quartz schist secara mikroskopis dimana plagioklas hadir sebagai porfiroblast.

Secara mikroskopis, sayatan quartz schist (O'Dunn dan Sill, 1986) berwarna abu - abu kebiruan hingga coklat muda, bentuk mineral idioblastik, struktur foliasi skitose (penjajaran mineral feldspar) dengan tekstur porfiroblas euhedral dengan lebih dari satu orientasi. Mineral penyusun adalah mineral feldspar plagioklas $(50 \%)$, kuarsa $(25 \%)$, aegerine-augite $(5 \%)$, garnet $(10 \%)$ dan terdapat vein kuarsa (Gambar 4f).

Satuan Lava Basal Dimito dapat disebandingkan dengan Formasi Tinombo (Teot) pada fasies gunungapi (Bachri, 2006) dengan dasar kesebandingan pada kesamaan ciri fisik litologi yang khas berupa adanya mineral zeolite, tekstur porfiro afanitik, dan ciri khas pillow lava (Gambar 4a). Satuan Lava Basal Dimito ditafsirkan terbentuk di lingkungan laut dalam yang merupakan dasar samudra. Hal ini didukung dengan adanya lava bantal dan asosiasi dengan batu gamping merah (Bachri, 2006).

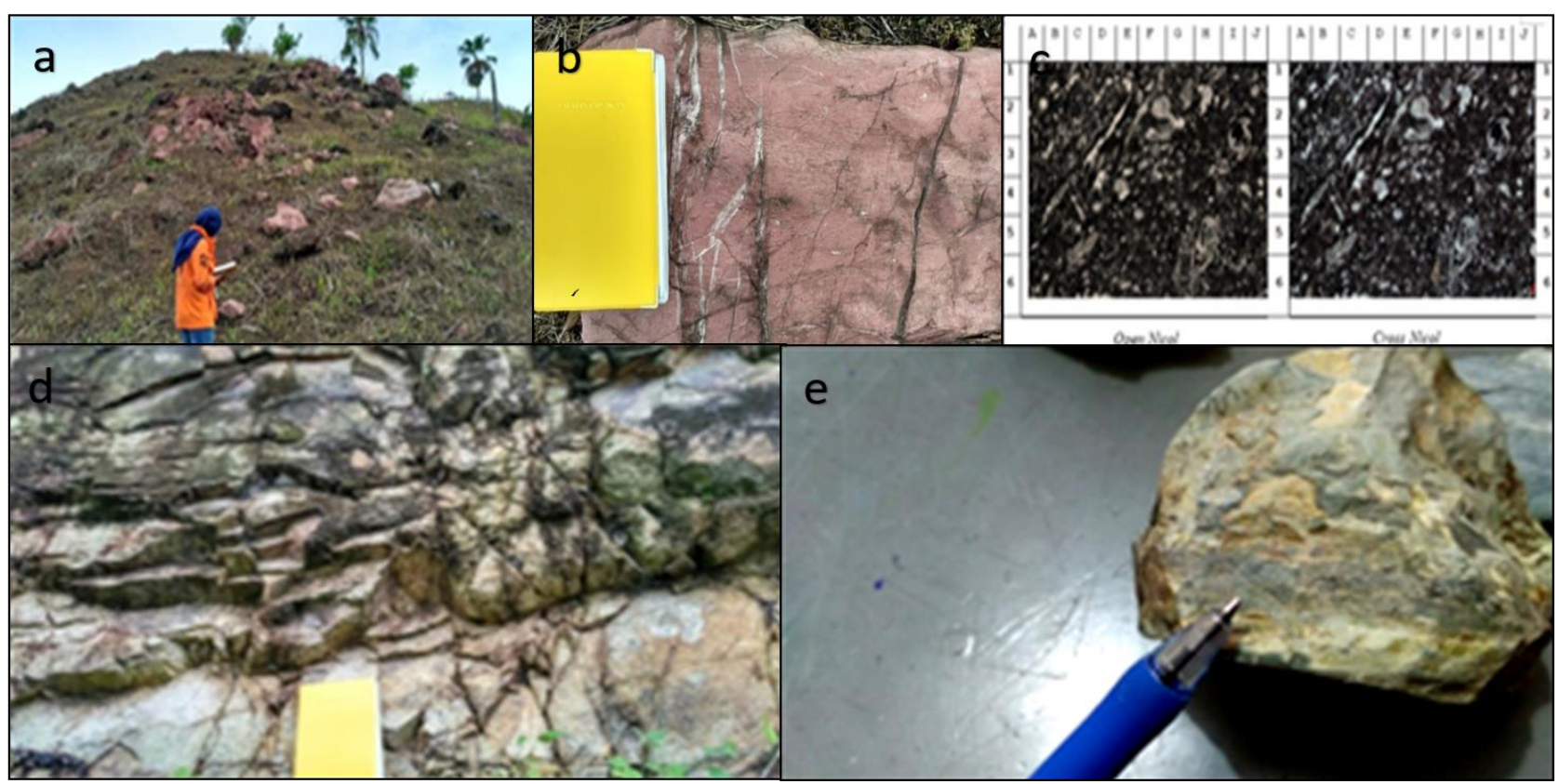

Gambar 5. Kenampakan pada satuan Wackestone Dimito dan satuan Andesit Kalidingin; a) singkapan satuan wackestone di lapangan yang dapat di kenali dengan warna merah yang khas, b) Kenampakan satuan wackestone dilapangan yang terdapat vein kalsit, c) Kenampakan wackestone dalam sayatan petrografi, d) Singkapan batuan andesit dengan adanya stuktur sheeting joint, e) Hand specimen dari batuan andesit dengan tekstur afanitik. 


\section{b. Satuan Wackestone Dimito}

Satuan ini menyebar setempat di selatan daerah penelitian yaitu di Desa Dimito dengan luas sekitar $2.5 \%$ atau $1.24 \mathrm{~km}^{2}$ dari total luas daerah penelitian. Satuan Wackestone Dimito mempunyai ciri-ciri yang khas yang bisa ditemui di lapangan (Gambar 5a). Ciri-ciri berwarna merah, struktur fossiliferous, tekstur masif, sortasi baik, rounded, kemas tertutup dan berbutir sangat halus, terdapat gash berupa mineral kalsit (Gambar $5 b$ ) yang bersifat karbonatan. Secara mikroskopis (Gambar $5 \mathrm{c}$ ), tersusun dari $15 \%$ fosil berupa bivalvia, crinoid, brasiopoda dan alga, 50\% mikrit dan $20 \%$ kalsit. Penamaan batuan secara mikroskopis mengacu pada kalsifikasi Dunham (1962) yaitu Wackestone.

Berdasarkan kesamaan ciri fisik litologi, satuan Wackestone Dimito dapat disebandingkan dengan Formasi Tinombo (Teot) pada fasies sedimen (Bachri, 2006) anggota batugamping merah, dimana satuan ini diendapkan pada Eosen hingga Miosen awal (Bachri dkk., 1994). Satuan ini berasosiasi dengan satuan Lava Basal Dimito dan tidak selaras dengan satuan batuan di atasnya, yaitu satuan Andesit Kalidingin. Satuan Wackestone Dimito ditafsirkan terbentuk di lingkungan laut dalam dengan bukti adanya kandungan fosil yang mencirikan pembentukannya relatif pada laut dalam (Bachri, 2006).

c. Satuan Andesit Kalidingin

Satuan ini menyebar luas di daerah barat penelitian. Luas penyebaran satuan ini sekitar $20.8 \%$ atau $10.12 \mathrm{~km}^{2}$ dari total luas daerah penelitian. Satuan ini terdapat di Desa Dimito, Dutula Hulapoduala, dan Desa Bongo 3. Ciri litologi (Gambar 5e) yang dapat diamati di lapangan pada satuan ini adalah warna abu - abu gelap hingga abu-abu kehijauan, dengan tekstur afanitik, subhedral - anhedral, intermediet vulkanik, terdapat urat kuarsa, bersifat masif dan kompak, namun pada beberapa tempat telah mengalami pelapukan, dan berstruktur kekar berlembar (sheeting joint) (Gambar 5d) sebagai salah satu penciri lava. Ciri litologi ini membedakannya dengan satuan Lava Basal Dimito pada anggota lava andesit.

Berdasarkan kesamaan ciri fisik litologi, satuan ini dapat disebandingkan dengan Formasi Dolokapa (Tmd) berdasarkan peta geologi regional Gorontalo lembar Tilamuta dengan umur Miosen tengah hingga Pliosen awal. Ciri yang ditemukan di lapangan seperti adanya kekar berlembar (sheeting joint) dan tekstur afanitik. Hubungan stratigrafi satuan ini dengan satuan sebelumnya selaras dengan batuan yang mengintrusinya yaitu satuan Granodiorit Bualo.

\section{d. Satuan Granodiorit Bualo}

Satuan ini tersebar di daerah sekitar Desa Bualo hingga Desa Bongo 4 yang tersingkap di tebing maupun di sungai (Gambar 6b). Luas penyebaran satuan ini sekitar $24 \%$ atau $11.76 \mathrm{~km}^{2}$ dari total luas daerah penelitian. Ciri litologi (Gambar 6c) dari satuan ini adalah berwarna abu-abu terang dan putih,

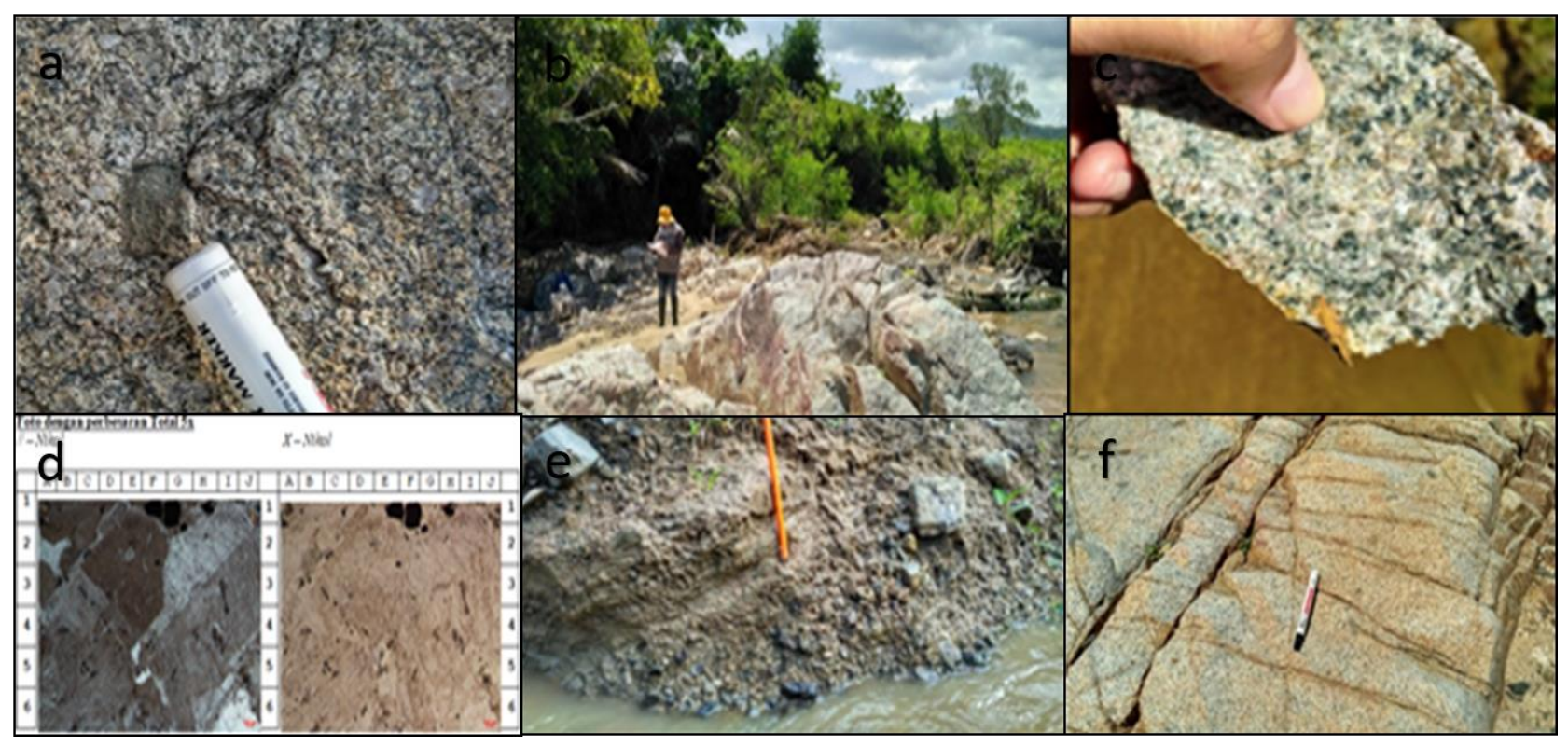

Gambar 6. Kenampakan pada satuan Granodiorit Bualo dan satuan Aluvial Bualo; a) menunjukkan adanya asimilasi xenolith, dimana terdapat xenolith batuan basal di batuan beku granodiorit, b) singkapan batuan granodiorit, c) Contoh hand specimen dari batuan granodiorit, d) Sayatan petrografi dari granodiorit, e) endapan alluvial yang terdiri dari fragmen batuan beku dan material lepas, f) shear joint pada singkapan di Desa Bualo. 
berstruktur masif, anhedral-subhedral, dengan homogenitas equigranular, besar butir faneritik, intermediate, dan hipokristalin. Komposisi mineral berupa plagioklas, quartz, ortoklas, biotit dan piroksen. Granodiorit dan monzonit kuarsa (Streckeisen, 1973) merupakan anggota dari satuan ini. Terdapat xenolith (Gambar 6a) pada batuan granodiorit yaitu basal.

Berdasarkan pengamatan petrografi (Gambar 6d) untuk batuan granodiorit, sayatan berwarna biru ke abu-abuan dan coklat tua, tekstur hipokristalin, euhedral - subhedral, hubungan antar Kristal equigranular, tekstur khusus berupa intergrowth mineral. Komposisi mineral plagioklas (20\%), ortoklas $(10 \%)$, anortoklas (5\%), quartz (35\%), dan hornblende (5\%). Berdasarkan kesamaan ciri fisik litologi, satuan ini dapat disebandingkan dengan Diorit Boliohuto (Tmbo) dengan umur Pliosen tengah (Bachri, 2006). Ciri yang ditemukan di lapangan bahwa satuan ini mengintrusi formasi sebelumnya dengan ditemukannya xenolith. Hubungan stratigrafi satuan ini selaras dengan satuan sebelumnya dan tidak selaras dengan satuan di atasnya (satuan endapan aluvial).

\section{e. Satuan Aluvial Bualo}

Satuan ini tersebar pada bagian utara daerah penelitian dengan luas penyebaran $10.2 \%$ atau $5 \mathrm{~km}^{2}$ dari total luas daerah penelitian. Ciri litologi (Gambar 6e) dari satuan ini terdiri dari material lepas dan berupa endapan yang belum mengalami kompaksi dengan fragmen batuan beku berupa andesit, granodiorit, dan basal, didominasi oleh tekstur berukuran lempung dan sebagian berukuran pasir bongkah. Tekstur disusun oleh hasil berbagai jenis rombakan batuan yang belum terkonsolidasi, namun dalam bentuk endapan. Bentuk butir dari rounded hingga sub-angular.

Mengacu pada umur regional maka satuan Aluvial Bualo ini terendapkan pada kala Holosen, dimana terisi oleh material-material lepas dan prosesnya masih berlangsung hingga sekarang. Satuan ini merupakan satuan termuda di daerah penelitian, hubungan satuan ini dengan satuan sebelumnya adalah tidak selaras.

\subsection{Struktur geologi}

Stuktur geologi yang berkembang pada daerah penelitian dianalisis dan interpretasi berdasarkan data dan pengukuran di lapangan. Terdapat data kekar, data sesar (pitch, plunge, trend, dan bidang sesar), zona breksiasi, struktur kekar kolom (columnar joint) dan kekar berlembar (sheeting joint).

a. Struktur Kekar

Kekar gerus (shear joint) (Gambar 6e) merupakan struktur kekar dominan yang ditemukan di lapangan. Hasil analisis menunjukkan bahwa arah tegasan relatif berarah timur laut - barat daya hingga barat laut- tenggara (Gambar $7 \mathrm{~b}$ ). Kekar berlembar mempunyai arah $\mathrm{N} 48^{\circ} \mathrm{E}$. Arah bidang kekar ini relatif ke arah barat. Pada daerah penelitian, columnar joint tersingkap di punggungan bukit dengan arah $\mathrm{N} 60^{\circ} \mathrm{E} / 76 \mathrm{SE}$ dan dapat diperkirakan arah aliran relatif tenggara.

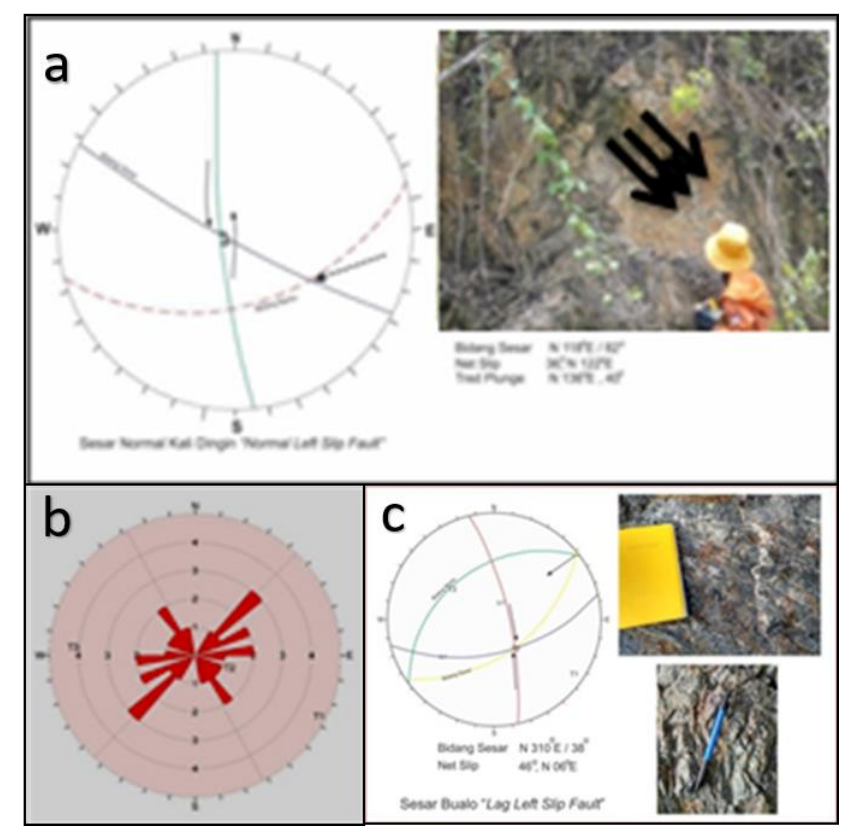

Gambar 7. Struktur geologi daerah penelitian; a) kenampakan bidang sesar di lapangan dan hasil pengolahan data menggunakan stereonet, b) hasil pengukuran shear joint menggunakan diagram roset, c) kenampakan stuktur penyerta gash dan kekar di lapangan, diolah menggunakan stereonet. 


\section{b. Sesar Normal Kalidingin}

Kedudukan bidang sesar ini (Gambar 7a) $\mathrm{N} 118^{\circ} \mathrm{E} / 82^{\circ} \mathrm{SW}$, nilai pitch sebesar $40^{\circ}$ serta net slip $40^{\circ}$, $\mathrm{N} 136^{\circ} \mathrm{E}$. Berdasarkan hasil analisis tegasan, gaya $\sigma 1$ merupakan stress terbesar yang mempengaruhi pergerakan sesar dan $\sigma 2$ merupakan stress yang tegak lurus dengan $\sigma 1$ dan memiliki magnitude kecil (tidak terlalu berpengaruh terhadap pergerakan sesar). $\sigma 3$ merupakan stress gaya yang tegak lurus dengan $\sigma 1$ dan $\sigma 2$ dan merupakan hasil dari tekanan yang diberikan oleh $\sigma 1$.

Berdasarkan hasil analisis menggunakan klasifikasi Rickard (1972), sesar ini termasuk dalam Normal Left Slip Fault. Sesar terletak pada daerah di sekitar Dusun Kalidingin dan pada kenampakan lapangan terlihat adanya offset yang turun serta ditemukannya bidang sesar dan slickenline.

\section{c. Sesar Mendatar Mengiri Bualo}

Kedudukan bidang sesar $\mathrm{N} 310^{\circ} \mathrm{E} / 38^{\circ} \mathrm{NE}$, nilai pitch sebesar $46^{\circ}$ serta net slip $6^{\circ}, \mathrm{N} 46^{\circ} \mathrm{E}$. Berdasarkan hasil analisis tegasan, $\sigma 3$ merupakan stress terbesar yang mempengaruhi pergerakan sesar. Arah tegasan relatif berarah barat laut - tenggara. Berdasarkan data pitch dan kemiringan sesar dan dianalisis menggunakan klasifikasi Rickard (1972), sesar ini termasuk dalam Lag Left Slip Fault (Gambar 7c).

\subsection{Sejarah geologi}

Satuan Lava Basal Dimito merupakan basement (Gambar 8.1) dan berasosiasi dengan Satuan Wackestone Dimito dengan susunan yang hampir sama (Silver et al., 1983) yaitu basal dan sedikit gamping yang berasal dari lingkungan laut dalam (Bachri, 2006). Satuan Lava Basal Dimito diperikirakan ditindih oleh andesitik Miosen bawah (Gambar 8.2) yang diperikirakan adalah Satuan Andesit Kalidingin. Satuan Andesit Kalidingin terdiri dari batuan andesit dan batuan basal yang mempunyai ciri berbeda dengan satuan andesit dan basal pada Lava Basal Dimito. Hal ini dipengaruhi oleh adanya kegiatan volkanisme andesitik dan aktivitas intrusif yang terjadi selama Miosen. Satuan ini diduga diendapkan di daerah lereng relatif curam dengan arus turbidit dan merupakan produk kegiatan gunungapi yang berbeda dengan satuan di bawahnya. Sebagian diendapkan di laut dalam sampai laut dangkal dan menunjukkan pendangkalan secara berangsur dari Formasi Tinombo yang sebelumnya merupakan laut dalam (Bachri, 2006).

Intrusi Granodiorit merupakan hasil kegiatan gunung api yang telah berlangsung selama Pliosen tengah dan menerobos (Gambar 8.3) batuan yang ada pada satuan batuan sebelumnya kemudian menghasilkan aktivitas metamorfisme kontak dengan hindrotermal. Setelah adanya intrusi dari Granodorit Bualo kemudian terjadi ketidakselarasan yang diakibatkan oleh proses eksogen pada kala Holosen. Proses ini mengubah sifat fisik kimia batuan. Vegetasi dan bentuk morfologi daerah penelitian

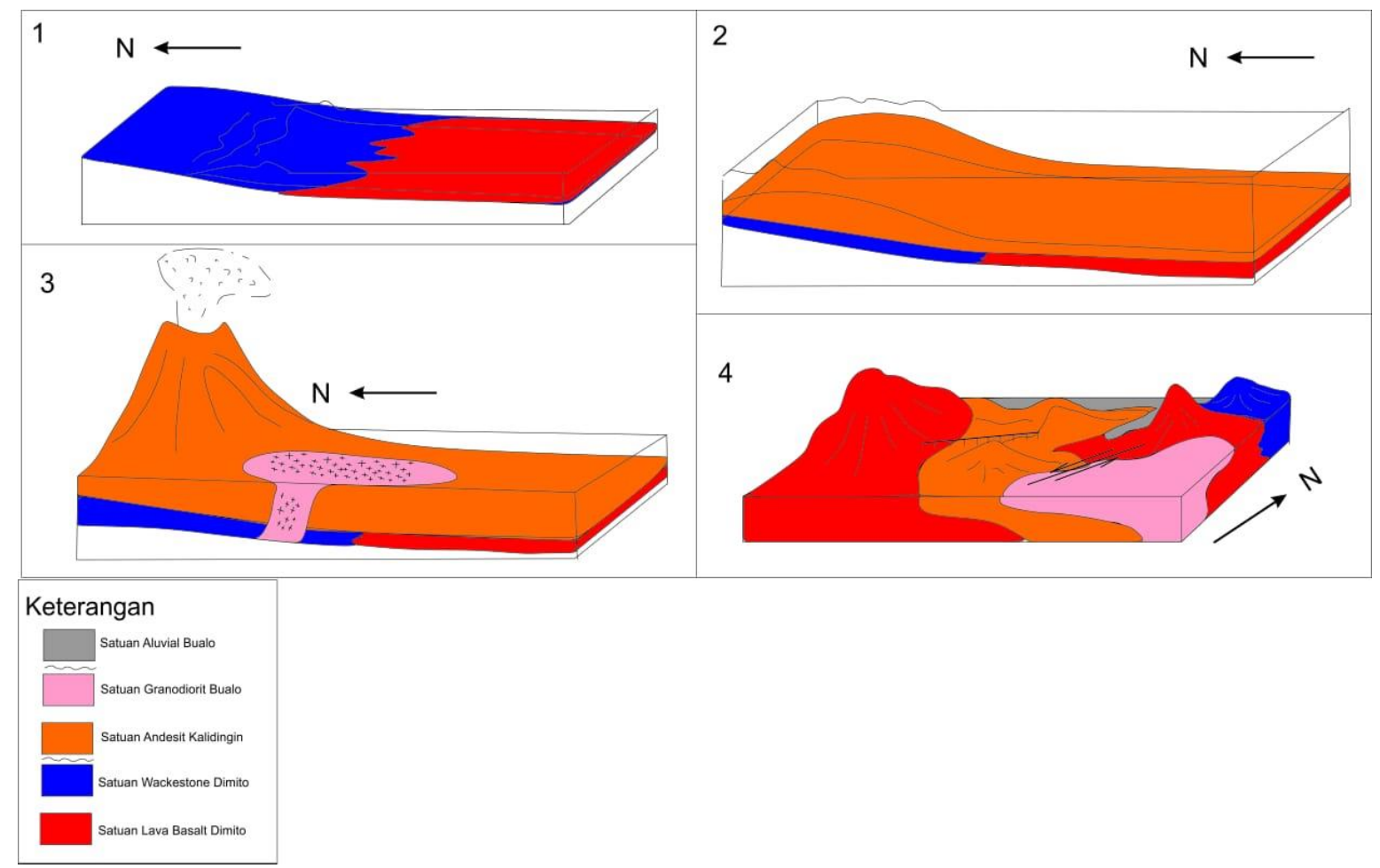

Gambar 8. Rekonstruksi sederhana model sejarah geologi daerah penelitian. 
yang bisa terlihat adalah adanya bentuk Roof Pendants atau atap intrusi karena sebagian dari sisa bukit Satuan Lava Basal Dimito masih tersingkap di lapangan. Batuan yang mengalami erosi dan pelapukan akibat proses eksogen akan mengalami proses perubahan fisik dimana batuan akan menjadi material kecil yang berukuran lempung hingga bongkahan dan terpisah dari batuan asalnya. Material ini dominan diendapkan di daerah sungai sehingga menutupi batuan sebelumnya (Gambar 8.4).

\section{Kesimpulan}

Secara geomorfik, daerah penelitian dibagi menjadi tiga yaitu Dataran Aluvial, Perbukitan Vulkanik, dan Perbukitan Denudasional. Stratigrafi daerah penelitian terbagi atas lima jenis satuan diurutkan dari Eosen hingga Holosen yaitu Satuan Lava Basal Dimito (Eosen awal), Satuan Wackestone Dimito (Eosen awal), Satuan Andesit Kalidingin (Miosen tengah), Satuan Granodiorit Buoalo (Pliosen tengah), dan Satuan Aluvial Bualo (Holosen). Struktur geologi yang bekerja pada daerah penelitian berupa kekar relatif berarah timur laut-barat daya hingga barat laut- tenggara. Sesar yang bekerja pada daerah penelitian yaitu Sesar Normal Kalidingin dan Sesar Mendatar. Sejarah geologi pada daerah penelitian berawal dari kala Eosen yaitu Satuan Lava Basal Dimito yang berasosiasi dengan satuan Wackestone Dimito, di atasnya diendapkan secara tidak selaras Satuan Andesit Kalidingin pada kala Miosen Tengah, kemudian diintrusi oleh Satuan Granodiorit Bualo pada Pliosen Tengah, dan akhirnya tererosi menjadi Satuan Aluvial Bualo yang bekerja hingga sekarang.

\section{Ucapan Terima Kasih}

Penulis mengucapkan terimakasih kepada Pemerintah Kabupaten Boalemo atas izin yang diberikan untuk melakukan penelitian di daerah Dimito dan sekitarnya. Ucapan terimakasih juga penulis sampaikan kepada pengurus Laboratorium Teknik Geologi yang menyediakan fasilitas untuk keperluan pengolahan dan analisis data.

\section{Referensi}

Bachri, S. (2006). Stratigrafi Lajur Vulkano- Plutonik Daerah Gorontalo, Sulawesi. JDSG Vol. XVI (2).

Bemmelen, R.W., van. (1949). The Geology of Indonesia, Vol. I-A, Gov. Printed Office, The Hague, $732 \mathrm{p}$.

Dunham, R.J. (1962). Classification of Carbonate Rocks According to Depositional Texture, dalam: Classification of Carbonate Rocks (ed. W.E.Ham),pp 108121. Mem. Am. Ass. Petrol. Geol. (1) Tulsa, USA.

Hall, R. (2009). Indonesia, Geology, London, Royal Holloway University Of London.

Hamilton, W. (1979). Tectonics of the Indonesian Region; Geol. Surv. Prof. Paper No. 1078; U.S. Gouvern. Print. Off., 345 p.

Howard A.D. (1967). Drainage Analysis In Geologic Interpretation A Summation. The American Association Of Petroleum Geologists Bulletin, 51:11.

O’Dunn, S., \& Sill, W.D. (1986). Exploring Geology: Introductory Laboratory Activities, APeek Publication.

Rickard, M.J. (1972). Fault classification - discussion: Geological Society of America Bulletin, v.83, p.2545-2546.

Silver, E. A., McCaffrey, R., Joyodiwiryo, Y. \& Stevens, S. (1983). Ophiolite emplacement and collision between the Sula platform and the Sulawesi island arc, Indonesia. Journal of Geophysical Research 88.

Streckeisen, A.L. (1978). IUGS Subcommission on the Systematics of Igneous Rocks. Classification and Nomenclature of Volcanic Rocks, Lamprophyres, Carbonatites and Melilite Rocks. Recommendations and Suggestions. Neues Jahrbuch für Mineralogie, Abhandlungen, Vol. 141.

Travis B. Russel. (1955). Classification Of Rocks. Colorodo School Of Mines. United State Of America.

Zuidam, R., A., Van. (1985). Aerial Photo Interpretation In Terrain Analysis and Geomorphologic Mapping. ITC, Smits Publ. Enschede, The Hagu Netherlands. 